\title{
Response of Machine Transplanted Rice (Oryza sativa L.) to Different Nitrogen and Phosphorus Levels during Rabi
}

\author{
P. Maheswara Reddy ", G. Krishna Reddy, K.V. Nagamadhuri, \\ G. Prabhakar Reddy, P. Sudhakar and B. Ravindra Reddy \\ Agronomy Division, Regional Agricultural Research Station, Tirupati - 517 502, \\ Andhra Pradesh, India \\ *Corresponding author
}

\section{A B S T R A C T}

Keywords

Nitrogen, Phosphorus, Grain yield, Straw yield and Economics.

Article Info

Accepted:

19 October 2017

Available Online:

10 December 2017
A field experiment was conducted during rabi, 2015-16 at farmer's field located at K.C. peta village of Tirupati rural mandal of Chittoor district of Andhra Pradesh for optimizing the nutrient requirement of machine transplanted rice under mechanized system of rice intensification (MSRI) in Randomized Block Design with factorial concept with four nitrogen levels $\left(80,120,160\right.$ and $200 \mathrm{~kg} \mathrm{~N}^{-1}$ ) and three phosphorus levels (40,60 and $80 \mathrm{~kg} \mathrm{P}_{2} \mathrm{O}_{5} \mathrm{ha}^{-1}$ ) replicated thrice. Application of $160 \mathrm{~kg} \mathrm{~N} \mathrm{ha}^{-1}$ and $200 \mathrm{~kg} \mathrm{~N} \mathrm{ha}^{-1}$ recorded statistically at par grain, straw yield and returns. Hence, application of nitrogen @ $160 \mathrm{~kg}$ $\mathrm{ha}^{-1}$ was found to be optimum dose for machine transplanted rice. Levels of phosphorus and their interaction with nitrogen have no significant influence on grain, straw yields and returns due to initial soil phosphorus buildup of experimental site. Hence, application of $160 \mathrm{~kg} \mathrm{~N} \mathrm{ha}^{-1}$ coupled with $40 \mathrm{~kg} \mathrm{P}_{2} \mathrm{O}_{5}$ ha $^{-1}$ can be recommended for machine transplanted rice for realizing higher yields and returns under mechanized system of rice intensification (MSRI).

\section{Introduction}

Rice is a major crop that is grown in more than 110 countries. India ranks first in the total area planted under rice with 44.1 million hectares, ranks second in the production after china with 158 million tonnes but, ranks $35^{\text {th }}$ with respect to its productivity. India's rice productivity $\left(2.42 \mathrm{t} \mathrm{ha}^{-1}\right)$ is far below the world's average productivity of $4.36 \mathrm{t} \mathrm{ha}^{-1}$ (India Stat, 2014). In Andhra Pradesh state, rice is the principal food crop cultivated in an area of $2.39 \mathrm{~m}$ ha with a production of $8.45 \mathrm{~m}$ $\mathrm{t}$ and productivity of $3.53 \mathrm{t} \mathrm{ha}^{-1}$ (Statistical Year Book, 2015). Demand for rice is growing every year but, area under rice crop is decreasing year by year due to water shortage and rapid urbanization and it is estimated that the rice requirement by 2025 AD would be 125 million tonnes (Kumar et al., 2009).

Hence, present food self-sufficiency has to be sustained and future food requirement has to be met at the current population growth rate of $1.5 \%$. To meet burgeoning population rice productivity has to be increased with good management practices under shrinking availability of land and water resources. Land preparation, transplanting and harvesting are 
the expensive and time consuming operations for successful rice cultivation. Manual transplanting of rice is the most common and popular practice being followed under lowland ecosystem. Manual transplanting is a tedious, laborious, time consuming operation which involves enormous drudgery and human stress in sweltering weather. It requires about $300-350$ man-h ha ${ }^{-1}$, which is roughly $25 \%$ of the total labour requirement of paddy cultivation. Labour scarcity during peak period of transplanting and escalating labour cost make the manual transplanting technique more expensive which invariably leads to delay in transplanting and resulting in reduction of yield and leads to less profit (Sreenivasulu, 2014).

Mechanization increases land and labour productivity by timely completion of farm operations and reduces the drudgery of humans and animals. Mechanically transplanted rice gave higher benefit-cost ratio of $34.46 \%$ compared to manually transplanted rice (Mohanty et al., 2010). Mechanization in transplanting through rice transplanter using mat nursery reduces the cost of cultivation since large area can be transplanted within a very short period (Mohanty et al., 2014).

Under mechanized system of rice intensification (MSRI), rice crop tends to produce profuse tillering due to planting of relatively younger seedlings at wider spacing. But all the tillers produced are not becoming productive due to less conversion ratio and even the grain filling is poor in tertiary tillers which ultimately causing the reduction in grain yield. This may be attributed to inadequate nutrition and long assigned vegetative period than conventional transplanting at recommended dose of nutrients. To avoid this starvation, due importance should be given to nutrient management under mechanized system of rice intensification. Keeping these points in view the present experiment was planned to optimize nitrogen and phosphorus levels for machine transplanted rice under mechanized system of rice intensification (MSRI) for southern zone of Andhra Pradesh.

\section{Materials and Methods}

A field experiment was carried out during rabi, 2015-16 at farmer's field of Sri P. Damodar Reddy located at K.C. peta village of Tirupati mandal of Chittoor district situated at an altitude of $182.9 \mathrm{~m}$ above mean sea level at $13^{0} 32^{\prime} 0^{\prime \prime} \mathrm{N}$ latitude and $79^{\circ} 24^{\prime} 25^{\prime \prime} \mathrm{E}$ longitude in southern agro climatic zone of Andhra Pradesh. The experimental soil was clay loam in texture, slightly alkaline in reaction (8.0), medium in organic carbon, $(0.54)$ and low in available nitrogen $(228 \mathrm{~kg}$ $\mathrm{ha}^{-1}$ ), high in available phosphorus (96 kg $\left.\mathrm{ha}^{-1}\right)$ and available potassium (516 $\left.\mathrm{kg} \mathrm{ha}^{-1}\right)$. The experiment was laid out in Randomized Block Design with factorial concept with four nitrogen levels $(80,120,160$ and $200 \mathrm{~kg} \mathrm{~N}$ $\left.\mathrm{ha}^{-1}\right)$ and three phosphorus levels (40,60 and $80 \mathrm{~kg} \mathrm{P}_{2} \mathrm{O}_{5} \mathrm{ha}^{-1}$ ) and replicated thrice. A uniform dose of $40 \mathrm{~kg} \mathrm{~K}_{2} \mathrm{O} \mathrm{ha}^{-1}$ was applied as basal dose to all the treatments. Entire P was applied basally as per treatment and $\mathrm{N}$ was applied in three equal splits at basal, 20 DAT and 40 DAT.

Nursery was raised in plastic trays filled with the soil and press mud cake in 70:30 ratio and placed in raised beds. Foliar spray of urea @ $0.5 \%$ was imposed at 10 DAS and machine transplanting was done at spacing $30 \mathrm{~cm} \times 13-$ $15 \mathrm{~cm}$ using 16 days old seedlings of Nellore Mashuri, medium duration variety with Yanmar - VP8D transplanter. Individual plots were kept at $5.0 \mathrm{~m}$ length $\times 5.0 \mathrm{~m}$ width. Growth parameters, yield attributes and yield, economics were worked out. All the necessary plant protection measures were taken up during the crop growth period. 


\section{Results and Discussion}

\section{Growth parameters}

Application of $200 \mathrm{~kg} \mathrm{~N} \mathrm{ha}{ }^{-1}$ recorded significant increase in plant height over 80 and $120 \mathrm{~kg} \mathrm{~N} \mathrm{ha}^{-1}$ and was comparable with $160 \mathrm{~kg} \mathrm{~N} \mathrm{ha}{ }^{-1}$. Significantly minimum plant height was recorded with the lower level of nitrogen application $\left(80 \mathrm{~kg} \mathrm{~N} \mathrm{ha}^{-1}\right)$ which was at par with $120 \mathrm{~kg} \mathrm{~N} \mathrm{ha}^{-1}$.

These results are in consonance with the findings of Chamely et al., (2015). Leaf area index of rice is closely related to grain production as it affects the rate of photosynthate production. It appears that plant height, tiller numbers and the aboveground biomass were significantly affected by the leaf area index which varied with the rates of nitrogen application. The rice crop responded well to the application of $200 \mathrm{~kg} \mathrm{~N}$ $\mathrm{ha}^{-1}$ by producing significantly larger leaf area and LAI at all crop growth stages.

Application of $200 \mathrm{~kg} \mathrm{~N} \mathrm{ha}^{-1}$ produced significantly larger LAI which however did not vary significantly from the application of $160 \mathrm{~kg} \mathrm{~N} \mathrm{ha}{ }^{-1}$. As compared to higher levels of nitrogen (160 and $\left.200 \mathrm{~kg} \mathrm{~N} \mathrm{ha}^{-1}\right), 120 \mathrm{~kg} \mathrm{~N}$ $\mathrm{ha}^{-1}$ resulted in significantly lesser LAI. Application of $80 \mathrm{~kg} \mathrm{~N} \mathrm{ha}{ }^{-1}$ recorded significantly lowest leaf area and LAI. Several researchers like Salem et al., (2011) and Verma et al., (2008) reported increased leaf area index with increasing nitrogen levels.

Application of $200 \mathrm{~kg} \mathrm{~N} \mathrm{ha}^{-1}$ recorded maximum dry matter production $\mathrm{m}^{-2}$ which was comparable with $160 \mathrm{~kg} \mathrm{~N} \mathrm{ha}^{-1}$ and significantly higher dry matter production over the application of $120 \mathrm{~kg} \mathrm{~N} \mathrm{ha}^{-1}$ and 80 $\mathrm{kg} \mathrm{N} \mathrm{ha}{ }^{-1}$. Application of $80 \mathrm{~kg} \mathrm{~N} \mathrm{ha}{ }^{-1}$ produced significantly lowest dry matter production $\mathrm{m}^{-2}$. Application of $160 \mathrm{~kg} \mathrm{~N} \mathrm{ha}^{-1}$ has produced significantly higher dry matter $\mathrm{m}^{-2}$ over the application of 120 and $80 \mathrm{~kg} \mathrm{~N}$ $\mathrm{ha}^{-1}$. The increase in dry matter accumulation is justifiable due to increasing rates of applied mineral $\mathrm{N}$ fertilizer. Higher level of $\mathrm{N}$ produced higher dry matter production, which is quite acceptable due to supply of enough nutrients to satisfy the demand of the crop.

Nitrogen being an important constituent of amino acids and protoplast, directly influences the plant growth and development through better utilization of photosynthates by producing more number of tillers and taller plants and thus, adequate supply of nitrogen results in higher biomass production in plants. Similar results were reported by Babu et al., (2013).

Levels of phosphorus and their interaction with nitrogen could not influence the rice crop significantly with respect to plant height, LAI and dry matter production. These results are in close agreement with the findings of Murthy et al., (2015) who observed comparable growth parameters at higher phosphorus levels but superior over control (without application of phosphorus) (Table 1).

\section{Yield attributes}

Yield attributes viz., number of panicles $\mathrm{m}^{-2}$, panicle length, number of filled grains panicle $^{-1}$ were significantly influenced by nitrogen levels and levels of phosphorus and their interaction with nitrogen did not significantly influenced during both the years.

The number of panicle $\mathrm{m}^{-2}$ increased linearly with increasing $\mathrm{N}$ levels and application of $200 \mathrm{~kg} \mathrm{~N} \mathrm{ha}^{-1}$ recorded maximum number of panicles $\mathrm{m}^{-2}$ which however, did not vary significantly with $160 \mathrm{~kg} \mathrm{~N} \mathrm{ha}^{-1}$ and superior over lower levels of nitrogen $(80$ and $120 \mathrm{~kg}$ $\mathrm{N} \mathrm{ha}^{-1}$ ). Application of $80 \mathrm{~kg} \mathrm{~N}^{-1} \mathrm{r}^{-1}$ recorded significantly lowest number of panicles $\mathrm{m}^{-2}$. 
Table.1 Growth, yield attributes, yield and economics of rice as influenced by N and P levels under MSRI

\begin{tabular}{|c|c|c|c|c|c|c|c|c|c|c|c|}
\hline Treatments & $\begin{array}{r}\text { Plant } \\
\text { height } \\
(\mathrm{cm})\end{array}$ & $\begin{array}{l}\text { Leaf } \\
\text { area } \\
\text { index }\end{array}$ & $\begin{array}{c}\text { Dry matter } \\
\text { production } \\
\left(\mathrm{kg} \mathrm{ha}^{-1}\right)\end{array}$ & $\begin{array}{c}\text { No. of } \\
\text { panicles } \\
\mathbf{m}^{-2}\end{array}$ & $\begin{array}{c}\text { Panicle } \\
\text { length } \\
(\mathrm{cm})\end{array}$ & $\begin{array}{c}\text { Filled } \\
\text { grains } \\
\text { panicle }^{-1}\end{array}$ & $\begin{array}{c}\text { Grain } \\
\text { yield (kg } \\
\left.\text { ha }^{-1}\right)\end{array}$ & $\begin{array}{c}\text { Straw } \\
\text { yield (kg } \\
\left.\text { ha }^{-1}\right)\end{array}$ & $\begin{array}{c}\text { Gross } \\
\text { returns } \\
\left(₹ \text { ha }^{-1}\right)\end{array}$ & $\begin{array}{c}\text { Net } \\
\text { returns } \\
\left(₹ \text { ha }^{-1}\right)\end{array}$ & $\begin{array}{l}\mathrm{B}: \mathrm{C} \\
\text { ratio }\end{array}$ \\
\hline \multicolumn{12}{|c|}{$\begin{array}{l}\text { Nitrogen Levels } \\
\left(\mathrm{kg} \mathrm{ha}^{-1}\right)\end{array}$} \\
\hline$N_{1}-80$ & 80.6 & 0.62 & 8570 & 349 & 18.7 & 123.1 & 5651 & 6590 & 87,329 & 41993 & 1.93 \\
\hline $\mathbf{N}_{2}-120$ & 82.9 & 0.91 & 9960 & 383 & 19.0 & 126.8 & 6540 & 7304 & $1,00,318$ & 54464 & 2.18 \\
\hline $\mathrm{N}_{3}-160$ & 85.4 & 1.04 & 11190 & 409 & 19.5 & 139.7 & 7235 & 8195 & $1,11,174$ & 64802 & 2.40 \\
\hline$N_{4}-200$ & 88.2 & 1.12 & 12000 & 424 & 19.8 & 146.0 & 7678 & 8662 & $1,18,369$ & 71479 & 2.52 \\
\hline SEd & 2.1 & 0.05 & 580 & 9.9 & 0.4 & 5.6 & 232 & 269 & 3718 & 3718 & 0.08 \\
\hline$C D(p=0.05)$ & 4.3 & 0.11 & 1160 & 20 & 0.8 & 11.6 & 480 & 556 & 7693 & 7693 & 0.17 \\
\hline \multicolumn{12}{|c|}{$\begin{array}{l}\text { Phosphorus Levels } \\
\left(\mathrm{kg} \mathrm{ha}^{-1}\right)\end{array}$} \\
\hline$P_{1}-40$ & 83.2 & 0.88 & 9970 & 387 & 19.1 & 131.7 & 6631 & 7439 & $1,01,789$ & 56674 & 2.25 \\
\hline$P_{2}-60$ & 84.3 & 0.92 & 10390 & 389 & 19.3 & 133.9 & 6657 & 7662 & $1,02,320$ & 56207 & 2.22 \\
\hline$P_{3}-80$ & 85.3 & 0.97 & 10940 & 397 & 19.4 & 136.0 & 7039 & 7963 & $1,08,783$ & 61670 & 2.31 \\
\hline SEd & 1.8 & 0.04 & 490 & 8.5 & 0.3 & 4.8 & 201 & 233 & 3220 & 3220 & 0.07 \\
\hline$C D(p=0.05)$ & NS & NS & NS & NS & NS & NS & NS & NS & NS & NS & NS \\
\hline \multicolumn{12}{|l|}{$\mathbf{N} \times \mathbf{P}$} \\
\hline SEd & 3.6 & 0.09 & 970 & 17.1 & 0.7 & 9.7 & 402 & 465 & 6440 & 6440 & 0.14 \\
\hline$C D(p=0.05)$ & NS & NS & NS & NS & NS & NS & NS & NS & NS & NS & NS \\
\hline
\end{tabular}


Panicle length varied significantly due to levels of nitrogen application and application of $200 \mathrm{~kg} \mathrm{~N} \mathrm{ha}{ }^{-1}$ recorded significantly longest panicle which was comparable with the application of $160 \mathrm{~kg} \mathrm{~N} \mathrm{ha}$ and significantly longer than $120 \mathrm{~kg} \mathrm{~N} \mathrm{ha}^{-1}$ and 80 $\mathrm{kg} \mathrm{N} \mathrm{ha}^{-1}$. Shortest panicle was recorded with the application of $80 \mathrm{~kg} \mathrm{~N}^{-1}$ which was at par with 120 and $160 \mathrm{~kg} \mathrm{~N} \mathrm{ha}^{-1}$. Increment in nitrogen levels increased the number filled grains panicle ${ }^{-1}$ and decreased number of chaffy grains panicle ${ }^{-1}$ and sterility $\%$. Application of $200 \mathrm{~kg} \mathrm{~N} \mathrm{ha-1}$ recorded maximum number of filled grains panicle $^{-1}$ which did not vary significantly with $160 \mathrm{~kg}$ $\mathrm{N} \mathrm{ha}^{-1}$. Application of $120 \mathrm{~kg} \mathrm{~N} \mathrm{ha}^{-1}$ resulted in significantly lesser number of filled grains panicle $^{-1}$ as compared to 160 and $200 \mathrm{~kg} \mathrm{~N}$ $\mathrm{ha}^{-1}$ but, comparable with $80 \mathrm{~kg} \mathrm{~N} \mathrm{ha}{ }^{-1}$. Application of $160 \mathrm{~kg} \mathrm{~N}^{-1}$ has recorded significantly more filled grains panicle ${ }^{-1}$ over 120 and $80 \mathrm{~kg} \mathrm{~N} \mathrm{ha}^{-1}$. Phosphorus levels and their interaction with nitrogen have shown non-significant response to number of panicle $\mathrm{m}^{-2}$, panicle length and number of filled grains panicle ${ }^{-1}$.

\section{Yield}

Grain and straw yields were increased with every increment in nitrogen levels. Maximum grain and straw yields were recorded with 200 $\mathrm{kg} \mathrm{N} \mathrm{ha}{ }^{-1}$ which was comparable with $160 \mathrm{~kg}$ $\mathrm{N}$ ha $^{-1}$. As compared to higher levels of nitrogen, application of $120 \mathrm{~kg} \mathrm{~N} \mathrm{ha}^{-1}$ resulted in significantly lower grain and straw yield. Application of $80 \mathrm{~kg} \mathrm{~N} \mathrm{ha}{ }^{-1}$ recorded significantly lowest grain and straw yield. Inspite of the fact that, the rice could not respond to phosphorus application and its interaction with nitrogen due to high initial soil available phosphorus, there was marginal increase in rice grain and straw yield. Highest grain and straw yield was recorded with the application of $80 \mathrm{~kg} \mathrm{P}_{2} \mathrm{O}_{5} \mathrm{ha}^{-1}$ which was comparable with 60 and $40 \mathrm{~kg} \mathrm{P}_{2} \mathrm{O}_{5} \mathrm{ha}^{-1}$.

\section{Economics}

Highest cost of production was observed with higher $\mathrm{N}$ and $\mathrm{P}$ level and it reduced with lower $\mathrm{N}$ and $\mathrm{P}$ level as it is directly related to the quantity of nitrogen and phosphorus applied in the form of urea and single super phosphate. As the grain and straw yields were significantly increased at higher doses, likewise maximum gross returns, net returns and highest B: C ratio were realized at $200 \mathrm{~kg}$ $\mathrm{N} \mathrm{ha}^{-1}$ which remained at par with $160 \mathrm{~kg} \mathrm{~N}$ $\mathrm{ha}^{-1}$ but statistically better returns and $\mathrm{B}$ : $\mathrm{C}$ ratio over the application of $120 \mathrm{~kg} \mathrm{~N} \mathrm{ha}^{-1}$ and $80 \mathrm{~kg} \mathrm{~N} \mathrm{ha}^{-1}$. Gross returns, net returns and $\mathrm{B}$ : $\mathrm{C}$ ratio shown non-significant differences with phosphorus levels and their interaction with nitrogen levels.

The results revealed that, application of 160 $\mathrm{kg} \mathrm{N} \mathrm{ha}{ }^{-1}$ and $200 \mathrm{~kg} \mathrm{~N} \mathrm{ha}{ }^{-1}$ recorded comparable growth parameters, yield attributes, yield and net returns. Hence, application of nitrogen @ $160 \mathrm{~kg} \mathrm{ha}^{-1}$ was found to be optimum dose for realizing higher yields. As phosphorus levels and their interaction with nitrogen shown nonsignificant differences in yield and returns due to initial soil phosphorus build up, phosphorus application at lower dose of $40 \mathrm{~kg}$ $\mathrm{P}_{2} \mathrm{O}_{5}$ ha $^{-1}$ can be recommended. Hence, it can be concluded that application of $160 \mathrm{~kg} \mathrm{~N} \mathrm{ha}^{-1}$ coupled with $40 \quad \mathrm{~kg} \quad \mathrm{P}_{2} \mathrm{O}_{5} \quad \mathrm{ha}^{-1}$ can be recommended for machine transplanted rice under high soil phosphorus build up condition for realizing higher yields and returns during rabi for southern agro climatic zone of Andhra Pradesh under mechanized system of rice intensification (MSRI).

\section{References}

Babu, P.V.R., Rao, Ch. P., Subbaiah, G and Rani, Y.A. 2013. Effect of different levels of nitrogen and phosphorus on growth and yield of kharif rice (Oryza 
sativa L.). The Andhra Agricultural Journal. 60(3): 528-534.

Chamely, S.G., Islam, N., Hoshain, S., Rabbani, M.G., Kader, M.A and Salam, M.A. 2015. Effect of variety and nitrogen rate on the yield performance of boro rice. Progressive Agriculture. 26(1): 6-14.

India Stat. 2014. http://www.indiastat.com/ agriculture/2/agricultural area land use/152/area under crops 19502015/ 48934/stats.aspx.

Kumar, R.M., Surekha, K., Padmavathi, Ch., Rao, L.V.S., Lathq P.C., Prasad, M.S., Babu, V.R., Ramprasad, A.S., Rupela, O.P., Goud, P.V., Raman, P.M., Somashekar, N., Ravichandran, S., Singh, S.P and Viraktamath, B.C. 2009. Research experiences on System of Rice Intensification and future directions. Journal of Rice Research. 2: 61-73.

Mohanty, D. K., Barik, K. C. and Mohanty, M.K. 2010. Comparative performance of eight row self-propelled rice transplanter and manual transplanting at farmer's field. Agricultural Engineering Today. 34(4): 15-17.

Mohanty, D.K., Barik, K.C. and Behera, D.
2014. Comparative performance of different establishment methods for sustainable rice production in Deogarh district of Odisha. Agricultural engineering Today. 38(3): 5-9.

Murthy D.K.M., Upendra R.A., Vijay D and Sridhar T.V. 2015. Effect of levels of nitrogen, phosphorus and potassium on performance of rice. Indian Journal of Agricultural Research. 49(1): 83-87.

Salem, A.K.M., Elkhoby, W.M., Abou, K and Ceesay. M. 2011. Effect of nitrogen fertilizer and seedling age on inbreed and hybrid rice varieties. American Eurasian Journal of Agriculture and Environmental Science. 1 1(5): 640-646.

Sreenivasulu, S and Reddy, P.B.H. 2014. Yield attributes and economics of machine transplanted rice. Madras Agricultural Journal. 100(10-12): 837839.

Statistical Year Book. 2015. Directorate of Economics and Statistics, Government of Andhra Pradesh, Hyderabad.

Verma, A.K., Pandey, N. and Tripathi, R.S. 2008a. Effect of planting time and nitrogen level on physiological parameters and grain yield of hybrid rice. Oryza. 45(4): 300-302.

\section{How to cite this article:}

Maheswara Reddy, P., G. Krishna Reddy, K.V. Nagamadhuri, G. Prabhakar Reddy, P. Sudhakar and Ravindra Reddy, B. 2017. Response of Machine Transplanted Rice (Oryza sativa L.) to Different Nitrogen and Phosphorus Levels during Rabi. Int.J.Curr.Microbiol.App.Sci. 6(12): 2683-2688. doi: https://doi.org/10.20546/ijcmas.2017.612.310 